DOI: 10.20472/IAC.2018.935.038

\author{
ALI PISKIN \\ DOGUS UNIVERSITY, Turkey \\ AYSE ILGUN KAMANLI \\ DOGUS UNIVERSITY, Turkey
}

\title{
THE FINANCIAL PERFORMANCE-CORPORATE REPUTATION NEXUS IN TURKEY
}

\begin{abstract}
:
There is a growing interest in corporate reputation among researches. Those who indicate the institutional and organizational stability as main source of economic growth state that any endeavor of corporates increasing production and employment is no longer sufficient for sustainable growth. It is obvious that national economies need intangible assets as far as tangible ones. Corporate reputation is one of these intangible assets. Reputation of any organization entirely depends on stakeholders' perception. The presence and level of this perception are affected by some factors associated with the positions of external and internal stakeholders. In this context, we investigate the potential linkage between corporate reputation and financial performance of corporates in Turkey between 2006 and 2016. This study aims to identify the financial determinants of corporate reputation as well as perception of stakeholders. Our data set is balanced panel. The dependent variable is the current reputation rankings which are output of Capital Magazine's survey of "Most Admired Companies of Turkey". This survey has been conducted since 1999, and respondents are professional managers. In order to have a balanced panel, we evaluate six companies which were in top 20 for the longest time together, and whose stocks are traded in Borsa Istanbul. Our independent variables are return on equity (ROE), current ratio (CR), debt ratio (DR), asset turnover ratio (ATR), growth of marketing expenditures, and previous reputation ranking of company. GDP growth rate, origin country of company, and company's sector are control variables. Data sample is based on Capital's survey, balance sheets and income statements of the companies. We employ a random-effects model for estimation. The preliminary results show that there are significant relationships between ROE, ATR, previous reputation ranking, company's sector, and current reputation ranking. While ROE would increase, the current reputation of the company would be higher. On the other hand, our model indicates that there is a positive relationship between ATR and the current reputation ranking. These first results will inevitably lead to management policy advices for professional managers to build a sustain reputation in micro level. Additionally, some macro policy proposals can be inferred through the institutional-based view.
\end{abstract}

\section{Keywords:}

Corporate reputation, financial performance, stakeholder's perception

JEL Classification: D22, L14, M14 